\title{
Ecology of African Civet (Civettictis civetta) in Arba Minch Forest, Arba Minch, Ethiopia
}

\author{
Dagnachew Mullu ${ }^{1 \star}$ and Mundanthra Balakrishnan ${ }^{2}$
}

\begin{tabular}{|c|c|}
\hline Abstract & Article Information \\
\hline \multirow{3}{*}{$\begin{array}{l}\text { The population density, diet and scent-marking of African civets (Civettictis civetta) were } \\
\text { assessed at Arba Minch Forest within Nechi Sar National Park in Arba Minch, Ethiopia. } \\
\text { The Civet population was estimated over a } 5 \text {-months period to be } 0.27 / \text { ha, of which } 0.16 \\
\text { were adults and } 0.11 \text { young. Civet diet was analyzed by examining } 578 \text { scats during the } \\
\text { same period to determine preference of adult Civets to plant material over animal } \\
\text { material and vice versa. This viverrid can be termed a generalist omnivore as per these } \\
\text { findings. Civets were found to use plants, metallic objects and poles to mark scent. Out } \\
\text { of the } 92 \text { scent marking sites observed, a vast majority were within } 100 \mathrm{~m} \text { radius of } \\
\text { civetries or latrine sites. In the wild, the amount of civet - the perineal gland secretion } \\
\text { collected from each marked site varied from } 0.0047 \mathrm{~g} \text { to } 0.98 \mathrm{~g} \text {, but in captivity } 0.034 \mathrm{~g} \\
\text { to } 2.0 \mathrm{~g} \text { was collected. Much as Ethiopia is the world's largest supplier of civet musk to } \\
\text { perfumery industry in Europe, its Civet farming practices needs to be regulated for } \\
\text { acceptable welfare standards. } \\
\text { Copyright@2014 STAR Journal. All Rights Reserved. }\end{array}$} & $\begin{array}{l}\text { Article History: } \\
\text { Received : } 15-06-2014 \\
\text { Revised : 30-08-2014 } \\
\text { Accepted : } 07-09-2014 \\
\end{array}$ \\
\hline & $\begin{array}{l}\text { Keywords: } \\
\text { African Civet } \\
\text { Population } \\
\text { Omnivorous generalists } \\
\text { Scat analysis } \\
\text { Scent marking } \\
\end{array}$ \\
\hline & $\begin{array}{l}\text { *Corresponding Author: } \\
\text { Dagnachew Mullu } \\
\text { E-mail: } \\
\text { dagnachew.mullu@yahoo.com }\end{array}$ \\
\hline
\end{tabular}

\section{INTRODUCTION}

The African Civet (Civetticus civetta) is an elusive, nocturnal, omnivorous and territorial scent marking viverrid, distributed throughout sub-Saharan Africa; usually close to perennial wetlands (Ray, 1995; Bekele Tsegaye et al., 2008a, 2008b). Not only is it the largest representative of Viverridae, but also a bioindicator of forest habitat dynamics akin to most other Civet species (Mudappa et al., 2010; Rabinowitz, 1991). Civettictis civetta is a stocky animal with a long body, and is shortlegged for its size although its hind limbs are noticeably larger and more powerful (Figure 1).

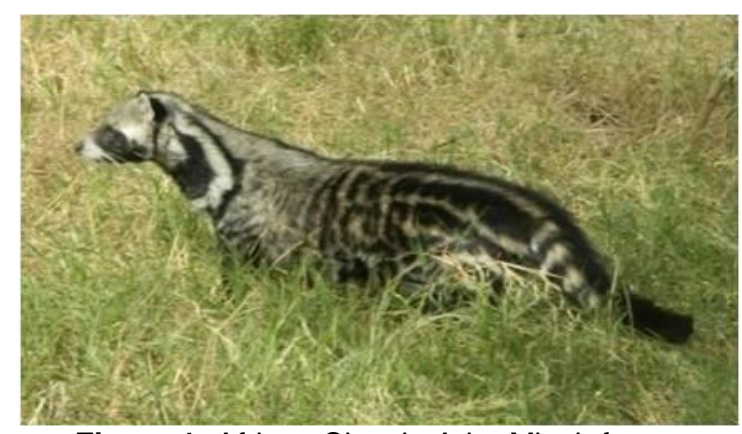

Figure 1: African Civet in Arba Minch forest

Understanding the ecology of the African Civet is important for its conservation, management, and husbandry as this species is increasing farmed for its 'civet' - a waxy and musky secretion of the perineal glands of both sexes much in demand in the perfume industry (Ralls, 1971; Ray, 1995; Eisenberg and Kleiman, 1972). This study addressed the following questions: (a) what is the population density of the African civet in Arba Minch Forest? (b) What are the food items of plant and animal origin consumed by them? (c) How important is scent marking for their communication? The results of the study are used to address its husbandry aspects given the commercial importance of the species.

\section{MATERIALS AND METHODS}

Study Site

The study was carried out between August 2012 and January 2013 in Arba Minch Forest, which is part of Nech Sar National Park (NSNP), and covers about 2120 ha. NSNP is a mix of woodlands, grasslands, and both groundwater and riverine forests located between 5051'6005 'N Latitude and 37032'-37048'E Longitude in the Southern Nations, Nationalities and Peoples Regional State (SNNPRS), in the Rift Valley floor between two lakes namely Abaya and Chamo (Aramde Fetene et al., 2011; Bolton, 1973) (Figure 2).

\section{Population Density}

A counting of dung pellets from civetries or latrines where Civets habitually defecate was conducted from 5 civetry sites namely Ashewa, Kella, Kontir-ketana, Biretdidly and Walo. The number of fresh droppings and their sizes were recorded on a daily basis to record age and structure of the population (Putman, 1984). 


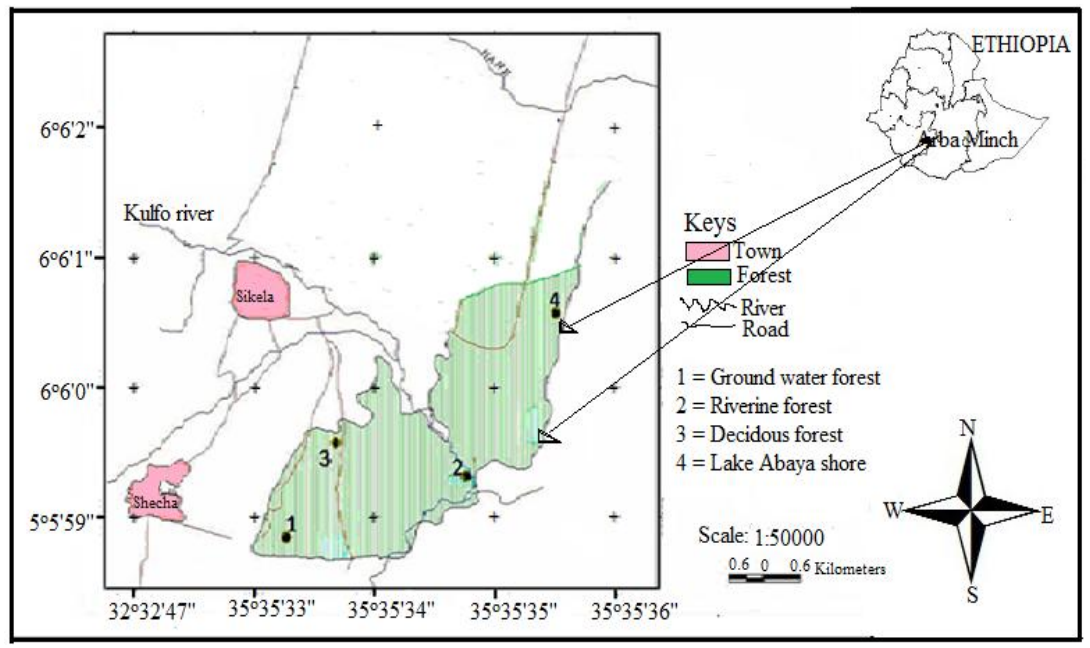

Figure 2: Map of the study area

\section{Population Density}

A counting of dung pellets from civetries or latrines where Civets habitually defecate was conducted from 5 civetry sites namely Ashewa, Kella, Kontir-ketana, Biretdidly and Walo. The number of fresh droppings and their sizes were recorded on a daily basis to record age and structure of the population (Putman, 1984).

\section{Diet Composition}

Gross and microscopic examination was conducted on 578 scat samples collected during the study period from the aforesaid civetry sites. The food items identified from the droppings of Civets were grouped under 7 categories viz., fruits, insects, invertebrates (millipedes and centipede) mammals (hare and rodent jaw, hair, limb, and skin), birds (feather, claw and beak), shrubs and non-food items (plastic material).

\section{Scent Marking}

The study area was searched extensively to locate the scent marking sites of Civets (Balakrishnan and Alexander, 1985; Balakrishnan, 1987; Bekele Tsegaye et al., 2008b). The height of the marking sites on the signpost was measured to identify suitable height at which Civets scent marked. The species of plants or type of objects marked were identified. Distance from civetries and tracks were measured to analyze the distribution of scent marks in the home range of the animal. Civet musk was collected in plastic bags from the scent marked sites and weighed. The time and site collected were recorded to assess the frequency of scent marking in the Civet's habitat (Wondimagegn Daniel, 2006). The preference of Civets to scent marked objects was assessed by 70 quadrants of $20 \times 10 \mathrm{~m}^{2}$ placed in the proximity of the civetries, as suggested by Wemmer (1977) and by observing the association of marking with the species of plant in the study area. The distance between each successive quadrat was $100 \mathrm{~m}$, and trees/plants on which Civets scent marked were identified to species level (Ranadll, 1977).

\section{Statistical Analysis}

SPSS software, Version 16.0, was used to identify the statistical significance of the results. Diet choice was calculated using frequency of occurrence of each of the food items expressed as percentage. Absolute frequency $(n / N)$ was the number of food items $(n)$ in relation to the scats analyzed $(N)$. Relative frequency $(r / R)$ was the relation of identified food items and the number of food items observed during analysis (R). One-way ANOVA test was used to identify the most preferred food item. Chisquare test of relative percentage frequency was performed to see significant food items in the diet. The total scent marked objects were identified. The level of preference to scent mark on these objects was calculated using frequency of occurrence of each of the objects expressed as percentage. The variation between scent marked objects was tested by using Chi-square test. The height of each of the scent marks was measured from the ground. The mean height at which scent marks were observed was calculated. The distance of scent marks from civetry sites and Civet paths were measured by a measuring tape.

\section{RESULTS}

\section{Population Density}

A total of 578 scats (adult $(n)=348$ and young $(n)=$ 230) were obtained from five different civetries. Figures 3 show the nature of droppings at civetries. The population density of the African Civets was $0.27 /$ ha., out of which 0.16 were adults and 0.11 young. There was a statistically significant variation between adult and young population $(x 2=24.09$, df $=1, P<0.05)$. The variation in the population estimates among the sites was also highly significant $\left(x_{2}=\right.$ 25.89, df $=4, P<0.05$ ) (Table 1). Civets in bush land habitat were fewer in January and more in November and this difference was statistically significant $((x 2=14.33, \mathrm{df}$ $=5, P<0.05)$

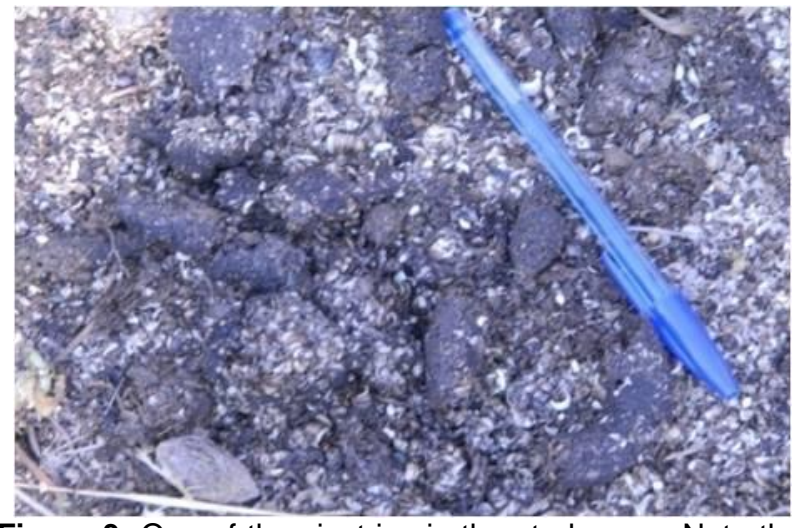

Figure 3: One of the civetries in the study area. Note the presence of large number of intact seeds and remains of invertebrates in the droppings 
Table 1: Population density estimate of Civets in the 5 Civetries of study area

\begin{tabular}{|c|c|c|c|c|c|c|}
\hline \multirow{3}{*}{ Site } & \multicolumn{6}{|c|}{ Number of Civets } \\
\hline & \multicolumn{3}{|c|}{ Wet season } & \multicolumn{3}{|c|}{ Dry season } \\
\hline & Adult & Young & Total & Adult & Young & Total \\
\hline Ashewa & $2.07 \pm 0.16$ & $1.89 \pm 0.16$ & $3.96 \pm 0.325$ & $2.03 \pm 0.14$ & $1.95 \pm 0.18$ & $3.98 \pm 0.32$ \\
\hline Kella & $2.32 \pm 0.16$ & $1.8 \pm 0.16$ & $4.12 \pm 0.329$ & $1.46 \pm 0.13$ & $1.82 \pm 0.17$ & $3.28 \pm 0.29$ \\
\hline Kontir-ketena & $2.22 \pm 0.10$ & $1.79 \pm 0.15$ & $4.01 \pm 0.258$ & $1.93 \pm 0.11$ & $1.62 \pm 0.21$ & $3.55 \pm 0.32$ \\
\hline Biret dildy & $2.15 \pm 0.14$ & $1.72 \pm 0.13$ & $3.87 \pm 0.268$ & $1.73 \pm 0.13$ & $1.88 \pm 0.16$ & $3.61 \pm 0.29$ \\
\hline Walo & $2.37 \pm 0.16$ & $2.3 \pm 0.19$ & $4.67 \pm 0.354$ & $1.72 \pm 0.15$ & $1.5 \pm 0.17$ & $3.22 \pm 0.32$ \\
\hline Total & $11.13 \pm 0.72$ & $9.5 \pm 0.80$ & $20.63 \pm 1.53$ & $8.87 \pm 0.65$ & $8.77 \pm 0.9$ & $17.64 \pm 1.54$ \\
\hline
\end{tabular}

\section{Diet Composition}

Twelve common food items were identified from Civet scats and a total of 688 occurrences of 13 items (including plastic from carry bags discarded from human areas) (Table 2). There was a statistically significant variation in food preference of Civets $(X 2=1.27$, df $=12, P<0.05)$. Fruits of Ficus spp., Euclea divonorum, Diospiros abyssinica, Tamarindus indica, Balanites aegyptiaca and banana $(48.85 \%)$ constituted the largest portion of the diet of the Civets. The fruits of Ficus spp. was the most frequent food item $(13.1 \%)$ found in the scats. Hair with bone accounted for $11.92 \%$ of the diet, followed by millipedes and centipedes (11.48\%); insects (11.05\%); Balanites aegyptiaca (9.01\%); Tamarindus indica (8\%); banana $(7.7 \%)$; Diospiris abyssinica $(6.54 \%)$; bird claw (5.54\%); snail (5.52\%); Euclea divonorum (4.5\%); shoots and leaves $(3.34 \%)$ and plastic $(2.47 \%)$ were the other items found in the scats.

Adult Civets preferred to feed on plant materials $(57.35 \%)$ to animal materials $(42.55 \%)$. This variation in food choice of adult Civets was statistically significant ( $X 2$ $=9.58, \mathrm{df}=1, P<0.05)$. Young Civets preferred to feed on animal materials (57.06\%) more than plant materials $(42.82 \%)$ items. This variation in food choice of young Civets was also statistically significant $(\mathrm{X} 2=4.96 \mathrm{df}=1$, $P<0.05)$.

Table 2: Diet composition of Civets in Arba Minch forest based on scat analysis

\begin{tabular}{lccc}
\hline \multicolumn{1}{c}{ Food items } & $\begin{array}{c}\text { Parts } \\
\text { eaten }\end{array}$ & $\begin{array}{c}\text { No. of } \\
\text { observation }\end{array}$ & $\begin{array}{c}\text { Percent } \\
(\%)\end{array}$ \\
\hline Ficus spp. & Fruit & 90 & 13.1 \\
Euclea divonorum & Fruit & 31 & 4.50 \\
Diospiros abyssinica & Fruit & 45 & 6.54 \\
Tamarindus indica & Fruit & 55 & 8.00 \\
Balanites aegyptiaca & Fruit & 62 & 9.01 \\
Banana & Fruits & 53 & 7.70 \\
Hair with bone & - & 82 & 11.92 \\
Bird claw & - & 37 & 5.54 \\
Insects & Whole & 76 & 11.05 \\
Millipede and centipede & Whole & 79 & 11.48 \\
Snail & Whole & 38 & 5.52 \\
Leaves and fibres & - & 23 & 3.34 \\
Plastic* & - & 17 & 2.47 \\
\hline Total & & $\mathbf{6 8 8}$ & $\mathbf{1 0 0}$ \\
\hline
\end{tabular}

\section{Scent Marking}

A total of 92 scent marked objects were identified from the study sites in Arba Minch forest. The Civets used plants, metallic objects and poles to scent mark (Figure 4). There was a high level of preference to mark on Balanites aegyptiaca (38.04\%), followed by metallic items $(19.56 \%)$. The variation between Balanites aegyptiaca and other marked objects was statistically significant ( $\mathrm{x} 2=$ $70.38, \mathrm{df}=7, P<0.05)$. The mean height at which scent marks were observed was $32 \mathrm{~cm}$. In the wild, the mean amount of civet musk that could be collected from each marked site (Table 3) varied from 0.0047 to $0.98(\mathrm{~g})$, but in captivity, 0.034 to $2(\mathrm{~g})$ civet musk was measured. Most scent marked sites (96.72\%) were within $100 \mathrm{~m}$ radius of civetries.

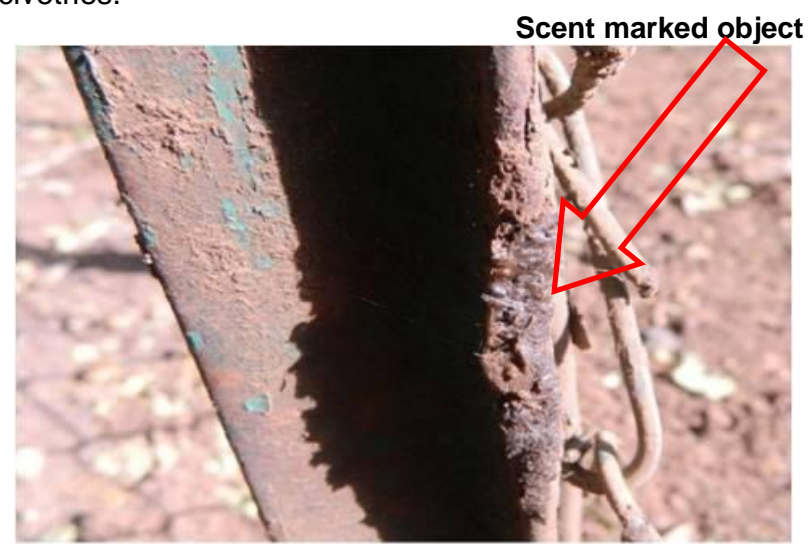

Figure 4: Scent mark of African Civets on a metallic object for many times

Table 3: Amount of Civet musk collected from scent marked sites

\begin{tabular}{c|l|c|l}
\hline $\begin{array}{c}\text { Marked } \\
\text { object }\end{array}$ & Species & $\begin{array}{c}\text { No. of } \\
\text { marked } \\
\text { objects }\end{array}$ & $\begin{array}{c}\text { Amount of } \\
\text { civet secretion } \\
\text { Mean } \pm \text { S.D., g }\end{array}$ \\
\hline \multirow{4}{*}{ Plants } & Balanite aegiptica & 35 & $0.154 \pm 0.044$ \\
& Acacia polyacantha & 13 & $0.0489 \pm 0.00185$ \\
& Kigelia africana & 7 & $0.0391 \pm 0.000926$ \\
& Acalypha fruticosa & 6 & $0.0814 \pm 0.0107$ \\
& Tamarindus indica & 7 & $0.0318 \pm 0.00091$ \\
Metallic & Eucalyptus spp. & 4 & $0.0129 \pm 0.0000547$ \\
materials & & 18 & $0.3384 \pm 0.1026$ \\
\hline Pole & & 2 & $0.318 \pm 0.116$ \\
\hline & & Total=92 & Mean=0.1088 $\mathbf{0 . 0 3 3}$ \\
\hline
\end{tabular}

\section{DISCUSSION}

Much as the African Civet is known for its fecundity, a population density estimate of $0.27 / \mathrm{ha}$ in Arba Minch forest, as hitherto determined, reinforces the shy and elusive nature of this nocturnal viverrid that renders the task of direct count quite difficult (Hongfa and Helin, 1995). Although scats can provide ample data for ecological research (Putman, 1984), a population density estimate of this civet using scat counts has its drawbacks including sporadic use, overlap and disturbance of civetries. Scats of adults and young Civets were observed throughout the study period - a pointer that Civets breed throughout the year. 


\section{Dagnachew Mullu and Mundanthra Balakrishnan}

This study reiterates that African Civets are generalist omnivores as evidenced by the presence of 13 items on scat analysis. African Civets are known to eat diverse food items (Smithers, 1986). Fruits of Ficus spp. were a major food items for an extended time. Fruits of Ficus spp. were also at a higher proportion in the diet of the African Civets in South Africa (Bothma, 1971). Pieces of bone with mammalian hair constituted the second highest proportion of the food in Civet scats, and the study area has a good population of rodents. Sixteen species of small mammals including two species of shrews were recorded from the study area (Demeke Datiko, 2007) and small mammals contribute to a major proportion the food of civets. Invertebrates such as insects, millipedes, and centipedes also formed Civet food and protein source (Pugh, 1998; Wondimagegn Daniel et al., 2011). The presence of non-food items in its diet, such as plastic from littered carry bags, can be associated with non-selective foraging habit of the animal.

Scent marking in Civets forms an intricate signaling and olfactory (Wondimagegn Daniel et al., 2011) communication system as evidenced from the location of scent marks and civetries in proximity to their movement paths. The Civets showed a preference in the use of Balanites aegyptiaca as sign post, and metallic objects came next. The use of scent marking by Civets could also be related to territory defense and to show case their reproductive status. Out of the 92 scent marks observed during the present investigation, only 32 were found to be re-marked. The low rate of re-marking might reflect the long lasting nature of the odor (Wondimagegn Daniel et al., 2011). In captive Civets, good diet seems to enhance the secretion of musk from their perineal glands.

\section{CONCLUSIONS}

The African Civet occupies a definite niche in Arba Minch forest, is resilient in wake of human disturbances, and can produce more musk in captivity than in wilderness. Good husbandry practices and welfare standards are needed to justify Civet farming given its high economic importance in Ethiopia.

\section{ACKNOWLEDGMENTS}

I gratefully acknowledge Horn of Africa Fund (STRONGBOW Project or HoAREC) and Addis Ababa University Department of Zoological Sciences for funding this project and facilitating my work.

\section{REFERENCES}

Aramde Fetene., Mengesha Getachew. and Bekele Tsegaye. (2011). Spatial distribution and habitat preferences of selected large mammalian species in the Nech Sar National Park (NSNP), Ethiopia. Nature and Science 9: 80-90.

Balakrishnan, M. (1987). Sebum-storing flank gland hairs of the musk shrew, Suncusmurinus viridescens. Journal of Zoology, London 213: 213-220.

Balakrishnan, M. and Alexander, K.M. (1985). Source of body odor and olfactory communication in south Indian mammals. Indian Review of Life Science 5: 277-313.
Sci. Technol. Arts Res. J., July-Sep 2014, 3(3): 99-103

Bekele Tsegaye., Afework Bekele and Balakrishnan M. (2008a). Feeding ecology of the African Civet Civettictis civetta in the Menagesha-Suba State Forest, Ethiopia. Small Carnivores Conservation 39: 19-24.

Bekele Tsegaye., Afework Bekele and Balakrishnan, M. (2008b). Scent-marking by the African Civet Civettictis civetta in the Menagesha-Suba State Forest, Ethiopia. Small Carnivores Conservation 38: 29-33.

Bolton, M. (1973). Notes on the current status and distribution of some larger mammals in Ethiopia. Mammalia 37: 562586.

Bothma, J.D.P. (1971). Food habits of some carnivora (Mammalia) from Africa. Annual Transfer Museum 27: 1525.

Demeke Datiko. (2007). Species Composition, Distribution, Relative Abundance and Habitat Association of Rodents. M.Sc. Thesis, Addis Ababa University, Addis Ababa.

Eisenberg, J. and Kleliman, D.G. (1972). Olfactory communication in mammals. Annual Review of Ecology and Systematics 3: 1-32.

Hongfa, X. and Helin, S. (1995). Reproductive behavior of small Indian Civets (V. indica). Zoos Print 10: 29-32.

Mudappa, D. Kumar, A. and Chellam, R. (2010). Diet and fruit choice of the brown palm civet Paradoxurus jerdoni, a viverrid endemic to the Western Ghats rainforest, India. Tropical Conservation Science 3: 282-300.

Pugh, M. (1998). Civet Farming. An Ethiopian Investigation. World Society for the Protection of Animals, London 272273.

Putman, R.N. (1984). Facts from faeces. Mammalian Review 14: 79-97.

Rabinowitz, A.R. (1991). Behavior and movement of sympatric Civet species in Huai Kha Khaeng Wildlife Sanctuary, Thailand. Journal of Zoology 223: 281-298.

Ralls K. (1971). Mammalian scent marking. Science 171: 443-449.

Randall, R.M. (1977). Aspects of the Ecology of Civets Civettictis civetta. M.Sc. Thesis, University of Pretoria, Pretoria.

Ray, J.C. (1995). Civettictis civetta. Mammlian Spcies 488: 17.

Smithers, R.H (1986). The Mammals of the South African Subregion. University of Pretoria, Pretoria. pp. 160-169.

Wemmer, C. (1977). Comparative ethology of the largespotted genet Genetta tigrina and some related viverrids. Smithsonian Contributions to Zoology 239: 1-93.

Wondimagegn Daniel (2006). Ecological Studies on African Civets (Civetticts civetta) in Jimma, Ethiopia. M.Sc. Thesis, Addis Ababa University, Addis Ababa.

Wondimagegn Daniel., Afework Bekele., Balakrishinan M. and Gurja Belay. (2011). Collection of African Civet Civettictis civetta perineal gland secretion from naturally scent marked sites. Small Carnivores Conservation 44: 14-18. 